\title{
O tribunal revolucionário como tribuna política em Cuba: uma análise dos casos "Marquitos" e "Ordoqui"
}

Giliard da Silva Prado ${ }^{1}$

\begin{abstract}
Resumo: este artigo aborda dois casos representativos da política de expurgos praticada pelo governo cubano contra indivíduos que pertenceram às fileiras revolucionárias, mas que, por terem sido vistos pelo líder da Revolução como obstáculos ou ameaças a seu poder, foram rotulados de "contrarrevolucionários" e "traidores da pátria" e submetidos aos tribunais revolucionários. Por meio de uma análise bibliográfica e de fontes relativas aos processos judiciais, este trabalho demonstra que os casos "Marquitos" e "Ordoqui" estavam interligados e consistiram em uma investida de Fidel Castro com o intuito de anular o poder político de dirigentes revolucionários cubanos que usufruíam de grande prestígio junto à União Soviética. Demonstra ainda que os tribunais revolucionários desempenharam também a função de uma tribuna política, evidenciando a insustentável aparência de legalidade jurídica que se pretendeu dar a julgamentos onde o que estava em jogo eram as condutas dos revolucionários e sua lealdade ao líder da Revolução.
\end{abstract}

Palavras-chave: Revolução Cubana; tribunal revolucionário; política.

\section{The revolutionary tribunal as political tribune in Cuba: analysis of the cases of "Marquitos" and "Ordoqui"}

\begin{abstract}
This paper discusses two representative cases of the policy of purges practiced by the Cuban government against individuals that belonged to revolutionary ranks, but that, being seen by the Revolution's leader as obstacles or threats to his power, were labelled as "counterrevolutionaries" or "homeland traitors" and submitted to revolutionary tribunals. Through bibliographic analysis and relevant sources of the legal processes, this work demonstrates that the cases "Marquitos" and "Ordoqui" were interconnected and constituted Fidel Castro's attempt to erase the political power of leading Cuban revolutionaries who enjoyed great prestige in the Soviet Union. This work also demonstrates that revolutionary tribunals had the function of a political tribune, upholding the unsustainable appearance of a legal order pretending to hand down justice, but what was at stake were the conducts of revolutionaries and their loyalty to the leader of the revolution.
\end{abstract}

Keywords: Cuban Revolution; revolutionary tribunal; politics.

\footnotetext{
${ }^{1}$ Doutor em História pela Universidade de Brasília - UnB; professor do Curso de História da Universidade Federal de Uberlândia - UFU (Campus Pontal). E-mail: giliardprado@ufu.br
}

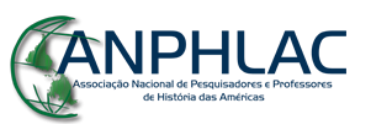

Revista Eletrônica da ANPHLAC, ISSN 1679-1061, №. 21, p. 04-33, Jul./Dez., 2016.

http://revista.anphlac.org.br 
Artigo recebido em: 19/02/2016

Artigo aprovado para publicação em: 12/05/2016

\section{Introdução}

A conquista do poder pelos rebeldes cubanos, em janeiro de 1959, assinalou a vitória de uma das principais revoluções ocorridas na América Latina durante o século XX. A Revolução Cubana promoveu mudanças significativas no país e causou grande repercussão para além das fronteiras nacionais, fazendo gravitar em torno da experiência revolucionária posições políticas antagônicas em um contexto marcado pela polarização ideológica da Guerra Fria.

No âmbito interno, não tardaram a surgir as mais diversas manifestações de oposição ao governo recém-instaurado, muitas das quais passaram a ser apontadas como posturas contrarrevolucionárias. Neste sentido, ao longo da experiência revolucionária cubana, não foram poucos os indivíduos que pertenceram às fileiras da Revolução $^{2}$ - na condição de guerrilheiros, membros das Forças Armadas Revolucionárias, intelectuais, artistas, integrantes do Partido Comunista de Cuba (PCC), etc. - e que, por não se enquadrarem em alguma das sucessivas metamorfoses ideológicas e políticas ditadas por Fidel Castro ao longo do processo revolucionário, foram apontados no discurso oficial da Revolução como "contrarrevolucionários" e/ou "traidores da pátria".

A trajetória de mais de cinco décadas da experiência revolucionária cubana é, pois, indissociável dos dissensos e lutas político-ideológicas entre o governo revolucionário e os seus opositores, os quais compuseram, no decorrer desse período, uma multifacetada dissidência cubana. Mas, quem são, afinal, os dissidentes?

\footnotetext{
${ }^{2}$ Para apontar apenas alguns célebres exemplos de indivíduos que, no decorrer de mais de cinco décadas de Revolução e por motivos diversos, atravessaram a fronteira simbólica que separava revolucionários de contrarrevolucionários, podem ser citados: Pedro Luis Díaz-Lanz, Manuel Urrutia Lleó, Huber Matos, Joaquin Ordoqui, Carlos Franqui, Guillermo Cabrera Infante, Heberto Padilla, Reinaldo Arenas, Arnaldo Ochoa, José Abrantes, Carlos Aldana, Roberto Robaina, Carlos Lage, Felipe Pérez Roque, etc.
}

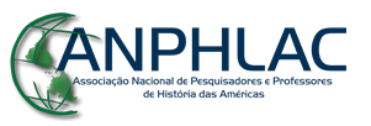

Revista Eletrônica da ANPHLAC, ISSN 1679-1061, №. 21, p. 04-33, Jul./Dez., 2016.

http://revista.anphlac.org.br 
A resposta a essa pergunta não deve ser buscada senão sob o signo da pluralidade. Diferentemente do que faz o discurso oficial da Revolução - que os apresenta indistintamente como "contrarrevolucionários" e que os define através de expressões e termos depreciativos e insultuosos: "traidores da pátria", "mercenários a serviço do imperialismo ianque" e "gusanos" (vermes) -, os dissidentes devem ser vistos a partir de sua heterogeneidade constitutiva, que se manifesta por meio de diferenças geracionais, étnicas, de classe social, de gênero, religiosas, ideológicas e políticas. Há, desse modo, entre os dissidentes: liberais, socialdemocratas, democratas cristãos, marxistas, martianos, esquerdistas, centristas, direitistas, socialistas, capitalistas, militantes cristãos, praticantes da santería, residentes em Cuba, residentes no exterior, etc.

O emprego do termo dissidente não deve ficar restrito ao indivíduo que fazia parte de agremiações políticas ou organizações sociais e que delas se separou para formar organizações similares. Ser dissidente não significa, pois, possuir um projeto de poder político, querer assumir o controle do governo ou se colocar inevitavelmente no front anticastrista - para empregar aqui uma terminologia bélica própria do discurso oficial do governo cubano -, ainda que haja alguns opositores que se enquadrem nesses quesitos. Em virtude de sua heterogeneidade constitutiva, os dissidentes integram grupos que apresentam diferentes pensamentos políticos, opiniões e aspirações sociais, havendo entre eles desde ativistas políticos até mesmo aqueles que são simplesmente críticos das políticas de governo, de suas reformas ou da ausência destas.

Para ser rotulado como "contrarrevolucionário" não é necessário, no entanto, tecer críticas ao regime. Basta não manifestar adesão irrestrita à ideologia oficial e às políticas do governo revolucionário. Desse modo, há entre os que são indistintamente considerados pelo governo cubano como "contrarrevolucionários": opositores de longa data; ex-defensores do regime que retiraram seu apoio à Revolução; e até mesmo indivíduos que, embora não tenham deixado de ser favoráveis ao governo revolucionário, foram apontados como obstáculos ou ameaças a seu poder e, por essa razão, submetidos aos tribunais revolucionários.

Este trabalho ocupa-se deste último grupo, ou seja, dos indivíduos que, mais do que apenas atravessarem a tênue fronteira simbólica que separa revolucionários de contrarrevolucionários, figuraram na condição de réus dos tribunais da Revolução Cubana. Não

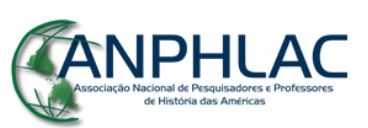

Revista Eletrônica da ANPHLAC, ISSN 1679-1061, №. 21, p. 04-33, Jul./Dez., 2016.

http://revista.anphlac.org.br 
se trata aqui, nos limites deste artigo, de realizar uma genealogia dos contrarrevolucionários cubanos ou de fazer uma análise de conjunto dos diversos episódios de defenestração política que marcam a história da elite dirigente da Revolução Cubana. O propósito deste artigo é examinar, por meio de uma análise bibliográfica e de documentos dos processos judiciais, dois casos - "Marquitos" e "Ordoqui" - que são representativos da política de expurgos praticada pelo governo revolucionário com o intuito de se livrar daqueles que eram vistos como ameaças ao seu poder.

Os dissensos e lutas político-ideológicas que marcam a trajetória da Revolução Cubana não ocorreram, no entanto, apenas entre o governo revolucionário e os seus declarados antagonistas internos e externos, tendo sido recorrentes também no âmbito do próprio poder revolucionário. Durante a fase da luta insurrecional da Revolução, formou-se uma ampla força de coalizão para combater a ditadura de Fulgencio Batista. Porém, tão logo ocorreu o triunfo da Revolução, a união dos diferentes movimentos e partidos oposicionistas não conseguiria disfarçar as divergências e disputas internas quanto aos rumos do processo revolucionário e ao grau de radicalização ou moderação das medidas reformistas. Isto ficou patente logo que se formou o governo revolucionário, que foi constituído por três grupos políticos principais: o Movimento 26 de Julho (liderado por Fidel Castro); o Diretório Revolucionário 13 de Março; e o Partido Socialista Popular (PSP). Com o avanço da Revolução e o intuito de conferir maior coesão ao poder revolucionário, fez-se a fusão desses três grupos políticos, que passaram a integrar, em 1961, as Organizações Revolucionárias Integradas (ORI), as quais deram origem em 1962 ao Partido Unido da Revolução Socialista de Cuba (PURSC) que, por sua vez, deu lugar, em 1965, ao atual Partido Comunista de Cuba (PCC). No entanto, "a fusão das forças revolucionárias tornou-se meramente nominal”. (BANDEIRA, 1998, p. 380) Na prática, o regime de partido único não conseguiu eliminar as contradições, divergências ideológicas e identidades políticas anteriores.

As várias metamorfoses ideológicas pelas quais passou a experiência revolucionária cubana, as divergências existentes no âmbito de sua cúpula política e as práticas repressivas do governo revolucionário fizeram com que diversos dirigentes da Revolução fossem alvos de uma política de expurgos e com que, dentre estes, muitos virassem réus nos tribunais revolucionários. Foi isto o que aconteceu, por exemplo, para citar apenas alguns dos casos mais

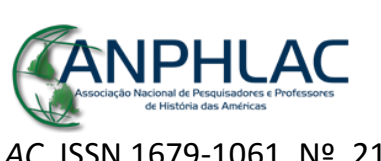

Revista Eletrônica da ANPHLAC, ISSN 1679-1061, №. 21, p. 04-33, Jul./Dez., 2016.

http://revista.anphlac.org.br 
célebres, com Huber Matos, Joaquín Ordoqui, Aníbal Escalante, Arnaldo Ochoa, José Abrantes, etc.

Os seguidos alvos da política de expurgos praticada pelo regime cubano evidenciam o pragmatismo político de Fidel Castro, para quem a permanência no poder e a continuidade da Revolução eram mais importantes do que o fiel cumprimento de uma plataforma política ou a filiação coerente a uma concepção ideológica, qualquer que fosse ela. Os primeiros expurgos praticados pelo governo cubano - ainda no ano de 1959, durante a fase em que o discurso oficial declarava que a Revolução era nacionalista e democrática - ocorreram entre os dirigentes revolucionários que se opunham à crescente influência comunista no governo e reivindicavam o restabelecimento da legalidade constitucional, o que implicava, entre outras medidas, na realização de eleições. Em seguida, já durante a fase socialista e marxista-leninista da Revolução, a partir de 1961, os alvos da política de expurgos foram comunistas de longa data, oriundos das fileiras do PSP, que possuíam vínculos estreitos com o Kremlin. A política de expurgos prosseguiu por outras fases da experiência revolucionária. A partir do final da década de 1980, por exemplo, teve como alvos os dirigentes revolucionários favoráveis ao reformismo socialista de caráter liberalizante, nos moldes do que estava sendo realizado na União Soviética e em países do Leste Europeu.

\section{O "caso Marquitos"}

Representativo das disputas de poder entre os principais dirigentes da Revolução e muito marcado por zonas de sombras é o episódio que envolve a defenestração, em 1964, de Joaquín Ordoqui e de sua esposa Edith García Buchaca, dois proeminentes comunistas oriundos das fileiras do PSP e que ocupavam, respectivamente, os cargos de vice-ministro das Forças Armadas Revolucionárias e de diretora do Conselho Nacional de Cultura. No centro dessa defenestração está o controverso "caso Marquitos", nome pelo qual ficou conhecido o julgamento de Marcos Rodríguez, militante da Juventude Socialista do PSP, acusado da delação que resultou no assassinato pelas forças policiais de Fulgencio Batista, em 20 de abril de 1957, de quatro integrantes do Diretório Revolucionário que estavam foragidos desde a fracassada

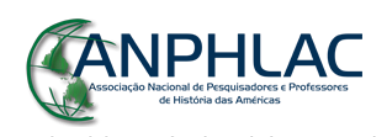

Revista Eletrônica da ANPHLAC, ISSN 1679-1061, №. 21, p. 04-33, Jul./Dez., 2016.

http://revista.anphlac.org.br 
tentativa de assalto ao Palácio Presidencial, ocorrida no dia 13 de março do referido ano. Esse episódio ficou conhecido como o "crime de Humboldt 7" em referência ao endereço - Rua Humboldt, n. 7, apartamento 201 - onde estavam escondidos os quatro foragidos da polícia que, desde então, ficaram conhecidos como "os mártires de Humboldt 7"3.

O “caso Marquitos" teve grande importância nas disputas de poder entre a elite dirigente da Revolução Cubana. Isto, porém, não se deveu diretamente à figura de Marcos Rodríguez que não ocupava nenhum cargo importante e tampouco podia ser considerado como uma ameaça ao poder de Fidel Castro -, mas sim aos vínculos que manteve com alguns dos principais dirigentes revolucionários e, em virtude disso, pelas informações privilegiadas que possuía a respeito de duas das três organizações políticas que formavam o governo revolucionário. Na condição de militante da Juventude Socialista do PSP, Marcos Rodríguez havia se infiltrado entre os principais dirigentes do Diretório Revolucionário para realizar atividades de espionagem política. Pouco depois do "crime de Humboldt 7", ele passou a ser tido como o principal suspeito de ter delatado os integrantes do Diretório Revolucionário que estavam foragidos e, por isso, asilou-se na embaixada do Brasil em Havana, de onde partiu para o exílio, passando pela Costa Rica e pela Argentina até estabelecer-se, em 1958, no México, país onde contou, a exemplo de outros integrantes do PSP, com o apoio dos também exilados Joaquín Ordoqui e Edith García Buchaca.

Com o triunfo da Revolução, Marcos Rodríguez retornou a Havana, onde foi preso e investigado pela suspeita de delação, mas, como não existiam provas suficientes para incriminálo e ele contava com o apoio de figuras proeminentes da política cubana, foi posto em liberdade e, poucos meses depois, ainda em maio de 1959, recebeu de Alfredo Guevara-membro do PSP e fundador do ICAIC (Instituto Cubano del Arte e Industria Cinematográficos) - uma bolsa para realizar estudos na Tchecoslováquia.

Temporariamente esquecido ou silenciado pelas autoridades cubanas, o crime de Humboldt 7 voltou à tona em janeiro de 1961, quando Esteban Ventura Novo - oficial de polícia

\footnotetext{
${ }^{3}$ Os quatro integrantes do Diretório Revolucionário vitimados no "crime de Humboldt 7" foram: Fructuoso Rodríguez, Juan Pedro Carbó, José Machado y Joe Westbrook. Parte dos documentos referentes ao julgamento de Marcos Armando Rodríguez Alfonso, “caso Marquitos", encontra-se disponível em: http://www.latinamericanstudies.org/marcos-rodriguez.htm Acesso em: 8 dez. 2015.
}

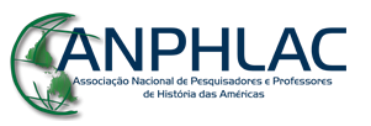

Revista Eletrônica da ANPHLAC, ISSN 1679-1061, №. 21, p. 04-33, Jul./Dez., 2016.

http://revista.anphlac.org.br 
que planejou aquela ação militar e que após o triunfo da Revolução exilou-se no México e, em seguida, nos Estados Unidos -, publicou o livro Memorias ${ }^{4}$, uma autobiografia na qual afirmou que os delatores dos mártires de Humboldt 7 foram dois integrantes do próprio Diretório Revolucionário 13 de Março: Raúl Díaz Argüelles e Faure Chomón Mediavilla, os quais, na época da publicação do livro, ocupavam, respectivamente, os cargos de chefe da Polícia Nacional Revolucionária e de Embaixador de Cuba na União Soviética. (ANGUREL, 2010) Coincidentemente, no mesmo período da divulgação do livro, ou seja, em janeiro de 1961, Faure Chomón - que após a morte dos ex-companheiros havia se tornado o principal líder do Diretório Revolucionário - acusou Marcos Rodríguez de realizar atos de espionagem na Tchecoslováquia para diferentes agências de inteligência. Em virtude dessa denúncia - que, pelo momento em que é feita, parece conferir plausibilidade à versão de Esteban Ventura a respeito da identidade dos delatores do crime de Humboldt 7 -, Marcos Rodríguez foi detido em Praga e encaminhado para Havana, onde, desta vez, permaneceu preso.

Passaram-se pouco mais de três anos desde a prisão de Marcos Rodríguez, em janeiro de 1961, até que o governo revolucionário decidisse, em março de 1964, levá-lo a julgamento, não pela denúncia acerca de atos de espionagem em Praga, que havia sido o motivo alegado para a sua prisão, mas sim pela acusação de ter sido o delator dos mártires de Humboldt 7 . No decorrer do período em questão, tiveram lugar dois acontecimentos que parecem ter sido preponderantes na decisão de transformar o que viria a ser chamado de "caso Marquitos" em uma arma política nas disputas de poder que ocorriam entre alguns dirigentes da Revolução. Em setembro de 1962, incomodado com o tempo que já havia permanecido na prisão, Marcos Rodríguez envia uma carta a Joaquín Ordoqui, por meio da qual pede que este interceda a seu favor e o ajude a sair da prisão. (CASTRO, 1964; CHOMÓN, 1964) Além disso, menciona o trabalho que desempenhou na Juventude Socialista do PSP e faz denúncias contra o Diretório Revolucionário. Um ano depois, em setembro de 1963, cópias dessa carta foram enviadas - não se sabe ao certo por quem - a Fidel Castro e Faure Chomón.

\footnotetext{
${ }^{4}$ Sob o título "Memorias: por el Teniente Coronel de la Policía de Cuba, Esteban Ventura Novo", esta autobiografia foi impressa em Miami, em novembro de 1960, e divulgada a partir de janeiro de 1961. Um exemplar deste livro encontra-se disponível no acervo da biblioteca da Universidade de Michigan. As informações referentes ao conteúdo desta autobiografia baseiam-se em ANGUREL (2010).
}

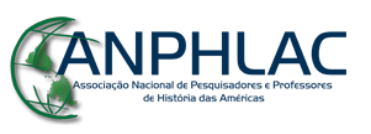


Em 14 de março de 1964 deu-se início ao julgamento do "caso Marquitos”, que se constituiu em um dos episódios mais emblemáticos dos usos do tribunal revolucionário como uma tribuna política em Cuba. Por meio desse julgamento, Fidel Castro logrou enfraquecer e, em alguns casos, anular politicamente importantes dirigentes revolucionários. Não se tratava ali de julgar uma questão jurídica, pois a culpabilidade do réu já era tida como certa. Antes de levar Marcos Rodríguez a julgamento, obteve-se dele - entre março e abril de 1963, portanto, ainda na prisão - uma confissão de culpa cuja espontaneidade é bastante duvidosa, uma vez que contradiz o teor da carta anteriormente enviada a Joaquín Ordoqui.

Na referida carta, Marcos Rodríguez aludia ao serviço de inteligência que prestava ao PSP, vigiando os passos do Diretório Revolucionário - ao qual se referia como "fuerza revolucionaria pequeño burguesa" -, mas declarava-se inocente em relação à acusação de que havia sido o delator dos mártires de Humboldt 7, questionando:

\begin{abstract}
¿Por qué soy precisamente yo a quien se señala como el traidor de Humboldt? ¿Por qué se han ceñido sobre mí todas las investigaciones? (...) ¿Qué poderoso interés había en encontrar una persona sobre la cual hacer recaer el peso de la responsabilidad? Responsabilizar para salvar responsabilidades? (RODRÍGUEZ apud CHOMÓN, 1964, p. 6-7 $)^{5}$
\end{abstract}

Nesse sentido, afirmava ser necessário "establecer nítidamente la diferencia que existe entre el hombre que le brinda información a su Partido y el hombre que le brinda información a la policía." (RODRÍGUEZ apud CHOMÓN, 1964, p. 6) Contudo, mais do que simplesmente declarar sua inocência, Marcos Rodríguez dava indícios de que possuía informações privilegiadas a respeito do crime e lembrava que no começo de 1959, quando chegou a ser preso como o principal suspeito da delação, havia pensado em tornar público tudo o que sabia, mas que tinha sido dissuadido por Joaquín Ordoqui, a quem aparentemente reprovava por ter

\footnotetext{
${ }^{5}$ A carta de Marcos Rodríguez a Joaquín Ordoqui não está disponível na íntegra. Alguns parágrafos dela constam nos testemunhos de Fidel Castro e Faure Chomón. Os trechos aqui citados foram retirados do depoimento deste último. (CHOMÓN, 1964)
}

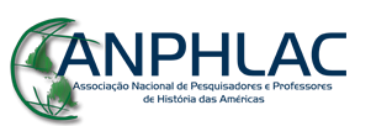

Revista Eletrônica da ANPHLAC, ISSN 1679-1061, №. 21, p. 04-33, Jul./Dez., 2016.

http://revista.anphlac.org.br 
sugerido deixar o problema ser solucionado de forma mais sigilosa por meio de reuniões políticas entre o PSP e o Diretório Revolucionário, conforme se verifica no trecho a seguir:

\begin{abstract}
En aquellos momentos yo le consulté a Ud. [usted], la idea de publicar una declaración situando cada cosa en su lugar. Recuerdo bien que usted me respondió que mi proposición no era táctica ni prudente ya que hubiese creado las condiciones para un sonado escándalo. ¿Resolver ese problema a través de las reuniones políticas que con el Directorio en aquellos días celebraban Carlos Rafael y otros camaradas? (RODRÍGUEZ apud CHOMÓN, 1964, p. 7)
\end{abstract}

No decorrer do julgamento, que ocorreu em duas instâncias, prevaleceram as discussões de caráter político. Marcos Rodríguez foi condenado, em primeira instância, à pena de morte. A culpabilidade do réu não se constituiu, todavia, no tema principal do debate. O que sobressaiu no tribunal foi a exposição das rivalidades e divergências - que diziam respeito tanto ao método de luta quanto às concepções ideológicas - entre o Diretório Revolucionário e o PSP durante o período insurrecional. Isto ficou particularmente acentuado no depoimento de Faure Chomón, que, ao defender-se das denúncias que pesavam contra ele próprio e rebater as críticas contra a sua anterior organização política, não apenas acusou Marcos Rodríguez de ser o culpado pela delação que vitimou quatro integrantes do Diretório Revolucionário, como também criticou o PSP. Ele evitou fazer críticas diretas aos dirigentes oriundos das fileiras do PSP, mas não deixou de reprovar o que, segundo seu ponto de vista, eram métodos equivocados desse partido, qualificando a infiltração de espiões em organizações revolucionárias como uma prática "que daba asco" (CHOMÓN, 1964, p. 10) e que tinha sido responsável por causar "un daño tan grande a la Revolución.” (CHOMÓN, 1964, p. 4)

$\mathrm{Na}$ enumeração dos erros do partido que estava sendo o alvo de suas críticas, Faure Chomón evocou a figura do já defenestrado Aníbal Escalante - que se encontrava exilado na União Soviética - para condenar os males causados pelo episódio do sectarismo, que ficou marcado pela colocação de "viejos militantes del PSP en todos los puestos claves de la Revolución”, abrindo espaço no aparato político para “oportunistas, delatores y traidores".

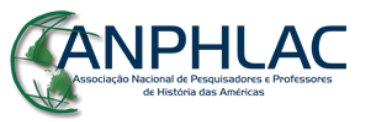

Revista Eletrônica da ANPHLAC, ISSN 1679-1061, №. 21, p. 04-33, Jul./Dez., 2016.

http://revista.anphlac.org.br 
(CHOMÓN, 1964, p. 10) Neste sentido, reprovava o PSP por ter admitido em seus quadros gente como Marcos Rodríguez, a quem buscava desqualificar por considerá-lo como "un fruto amargo del sectarismo" (CHOMÓN, 1964, p. 3), um indivíduo oportunista e imoral em busca de notoriedade, um “desviado" e "invertido". (CHOMÓN, 1964, p. 9) Este último termo aludia à homossexualidade do réu que, tal como um grande tabu, quase nunca era referida pelo próprio nome, mas que foi fartamente mencionada por meio de adjetivos eufêmicos em diferentes depoimentos no decorrer do processo judicial para explicar a conduta contrarrevolucionária e traiçoeira que lhe era atribuída no crime de Humboldt 7. Essa relação de causalidade entre homossexualidade e posturas equivocadas é expressa no trecho abaixo:

Los tipos como Marcos Rodríguez, exhibicionistas ansiosos de notoriedad, son los mismos que en el año 1959 cuando el Congreso Latinoamericano de Juventudes, vimos en una serie de delegaciones trotskistas. No recuerdo jamás haber visto tanta gente extraña y estrafalaria junta y pensaba yo como posiciones equivocadas pueden atraer a elementos extraños y enfermos ajenos a la Revolución. (CHOMÓN, 1964, p. 12)

Na opinião de Faure Chomón, Marcos Rodríguez não havia se instalado na Universidade de Havana para combater a tirania de Fulgencio Batista, mas sim "el único movimiento de acción de masas contra la tiranía, que era el que desarrollaban las organizaciones de estudiantes" (CHOMÓN, 1964, p. 12), as quais, por sua vez, deram origem ao Diretório Revolucionário. Depois das críticas feitas ao PSP por ter admitido em seus quadros um "elemento desviado", Faure Chomón buscou explicar o porquê de os integrantes do Diretório Revolucionário terem permitido a aproximação desse mesmo "elemento". Afirmou que, apesar de ser conhecida a militância de Marcos Rodríguez na Juventude Socialista do PSP, eles imaginaram que este tinha se decidido pelos métodos de luta do Diretório. Todavia, Faure Chomón preocupou-se em afirmar que Marcos Rodríguez, desde o princípio, não havia lhe causado uma boa impressão "por su tipo, por su forma de vestir, con unas sandalias en que llevaba dos centavos americanos". (CHOMÓN, 1964, p. 12) Além disso, buscou deixar claro o

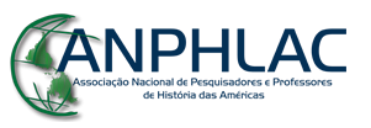

Revista Eletrônica da ANPHLAC, ISSN 1679-1061, №. 21, p. 04-33, Jul./Dez., 2016.

http://revista.anphlac.org.br 
seu ponto de vista sobre qual devia ser o destino do réu - e permitiu entrever a eficácia da pedagogia do medo associada aos tribunais revolucionários -, ao finalizar o seu depoimento com a seguinte exortação: “juzguemos a Marcos Rodríguez que en él también vamos a enterrar, a sepultar el sectarismo". (CHOMÓN, 1964, p. 13)

O paredão foi o destino definido para o réu pelo tribunal que o julgou em primeira instância. $\mathrm{O}$ fato de a defesa de Marcos Rodríguez ter impetrado um recurso por meio do qual solicitava a reavaliação da sentença que estabeleceu a pena de morte, levando o julgamento a um tribunal de segunda instância, apenas criava a aparência de uma legalidade jurídica que, na prática, não foi respeitada. Assim como havia acontecido em julgamentos anteriores, coube a Fidel Castro - que era, de fato, a última instância do poder em Cuba - a aplicação da justiça revolucionária. Formalmente, ele desempenhava o papel de testemunha de acusação diante de um tribunal encarregado de julgar o recurso que tentava anular a pena de morte estabelecida para o réu Marcos Rodríguez. Em termos práticos, porém, foi possível constatar que o líder cubano acumulava as funções de interrogar, testemunhar, e julgar, bem como que o tribunal, uma vez mais, converteu-se em uma tribuna política, onde o que estava em jogo era a avaliação das condutas de outros dirigentes da Revolução.

Nesta etapa do julgamento do "caso Marquitos", Fidel Castro utilizou como prova das alegações que fez durante seu longo depoimento um interrogatório de caráter privado a que submeteu o réu Marcos Rodríguez depois de encerrada a audiência em que este havia sido condenado à morte. Diante do tribunal que estava julgando o caso em segunda instância, o réu - cabisbaixo, em silêncio e com sua expressão fisionômica parcialmente encoberta atrás dos óculos escuros que utilizava - ouvia o líder cubano justificar, em nome da "verdade", o fato de ter realizado "algunas gestiones y esfuerzos personales" com o objetivo de que fossem esclarecidas as "incógnitas" do caso e, em seguida, expor tanto as perguntas que havia feito quanto as respostas obtidas naquele peculiar interrogatório. Antecipando-se a eventuais críticas, Fidel Castro declarou ter dito ao réu que aquele interrogatório não devia ser entendido como um "abuso de poder" e tampouco tinha o propósito de levá-lo a um esgotamento "físico y mental”. A isto, Marcos Rodríguez, como alguém que seria incapaz de atribuir ao comandante em chefe da Revolução uma conduta incorreta, teria retrucado: "yo no puedo pensar eso de usted". Em suas sucessivas respostas, tal como reproduzidas por Fidel Castro, o réu teria

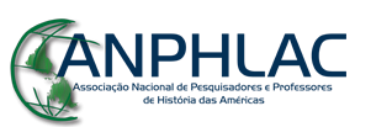

Revista Eletrônica da ANPHLAC, ISSN 1679-1061, №. 21, p. 04-33, Jul./Dez., 2016.

http://revista.anphlac.org.br 
representado a si mesmo como alguém que não tinha suficiente "valor" e "valentía moral", reconhecido possuir uma "mentalidad sectaria mil veces despreciable" e, por isso, declarado não merecer "ninguna oportunidad". (CASTRO, 1964, p. 61) Ainda no que se refere à defesa dos métodos utilizados pela Revolução para interrogar os acusados, Fidel Castro destacou que os interrogatórios anteriores a Marcos Rodríguez, feitos por agentes da segurança do Estado, também foram marcados pela correção, pois para descobrir "el delito" os revolucionários jamais se valiam da "tortura", recorrendo, em vez disso, "a la inteligencia”. (CASTRO, 1964, p. 64)

Logo no início de seu depoimento, Fidel Castro declarou que considerava "con absoluta convicción culpable al acusado”. (CASTRO, 1964, p. 60) Essa declaração não foi, porém, o único indício de que a pena anteriormente imposta ao réu não seria modificada. Mais adiante, enquanto comentava o interrogatório que havia conduzido pessoalmente, revelou ter recomendado a Marcos Rodríguez que ele não continuasse "haciendo daño aun después de muerto". (CASTRO, 1964, p. 61) O dano a que o líder da Revolução se referia era a vinculação dos dirigentes do PSP ao caso, uma vez que o crime de delação atribuído a Marcos Rodríguez tinha ficado associado ao serviço de inteligência que ele prestava em sua militância na Juventude Socialista desse partido. Como isso comprometeria a imagem de uma das forças políticas que integravam o poder revolucionário, o objetivo principal de Fidel Castro ao expor o resultado do interrogatório, que afirmava ter realizado, foi estabelecer como a versão verdadeira dos fatos o argumento de que a delação dos mártires de Humboldt 7 não teve natureza política, tendo sido resultante de uma motivação estritamente pessoal do réu, de um sentimento de mágoa que este teria nutrido em relação às vítimas, versão que, conforme se verá mais adiante, será sustentada e apresentada com mais detalhes pelo próprio advogado de defesa de Marcos Rodríguez.

O líder da Revolução Cubana ocupou-se principalmente em negar a natureza política de um crime de delação que colocaria em evidência o antagonismo e as disputas de poder entre as organizações revolucionárias. Neste sentido, reprovou Faure Chomón por ter, ainda que "involuntariamente", conferido um caráter político ao julgamento, quando o lugar correto para discutir algumas daquelas questões expostas no tribunal revolucionário teria sido a Direção Nacional do Partido Unido da Revolução Socialista de Cuba, cuja unidade, segundo o líder cubano, tinha sido colocada em dúvida naquele julgamento. Apesar de fazer essa crítica, Fidel

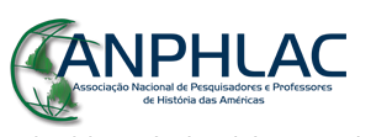

Revista Eletrônica da ANPHLAC, ISSN 1679-1061, №. 21, p. 04-33, Jul./Dez., 2016.

http://revista.anphlac.org.br 
Castro tinha afirmado, instantes antes, que o Tribunal de Apelação era também “el Tribunal del Pueblo" (CASTRO, 1964, p. 60) e, com base nessa perspectiva, considerou que o julgamento - que estava sendo transmitido pela rede nacional de TV - era um "vehículo de información para el pueblo". (CASTRO, 1964, p. 66)

Para dar informações ao povo cubano acerca do "caso Marquitos", Fidel Castro valeuse fundamentalmente de dois documentos: o interrogatório que ele próprio realizou ao final da primeira etapa do julgamento e a confissão de culpa que, havia aproximadamente um ano, tinha sido obtida do réu. A respeito deste último documento, buscou justificar o intervalo de tempo transcorrido desde a obtenção da confissão até que o réu fosse levado ao tribunal, argumentando que havia ali "cuestiones delicadas" que afetavam "a personas, al pueblo y a la Revolución”. Segundo o líder cubano, essa confissão de culpa devia ser cuidadosamente tratada

(...) no solo porque traía imputaciones a una compañera de la Revolución [Edith García Buchaca], compañera además de un dirigente de la Revolución [Joaquín Ordoqui], sino también, por contener informaciones que de no ser total y absolutamente esclarecidas, podían causar daños a las relaciones en el seno de nuestro Partido, sino además, porque las circunstancias que rodean ese caso de Marcos Rodríguez, son más que suficientes, para que esta cuestión se estudiase bien, bien, bien. (CASTRO, 1964, p. 66)

Em nome do tratamento cuidadoso que o caso requeria, Fidel Castro encarregou-se de interpretar diante do tribunal o documento em que constava a confissão de culpa de Marcos Rodríguez para que não se confundisse "la veracidad y la mentira, el dato cierto con la invención”. (CASTRO, 1964, p. 66) Para tanto, intercalava a leitura dos trechos da confissão que considerava necessários ao "esclarecimiento político" (CASTRO, 1964, p. 67) com os seus comentários sobre o que julgava ser verdadeiro ou falso. Desse modo, e conforme notou com muita propriedade o historiador e literato cubano Enrique Del Risco, Fidel Castro atuou no julgamento "como árbitro supremo de la unidad revolucionaria y su principal representante". (DEL RISCO, 2009) De fato, depois de terem sido expostas no tribunal tanto as denúncias e acusações que Marcos Rodríguez fez ao Diretório Revolucionário quanto as que Faure Chomón

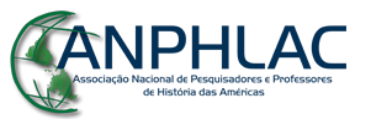

Revista Eletrônica da ANPHLAC, ISSN 1679-1061, №. 21, p. 04-33, Jul./Dez., 2016.

http://revista.anphlac.org.br 
fez ao Partido Socialista Popular, Fidel Castro encarregou-se de isentar de culpa ambas as organizações políticas, as quais, junto com o Movimento 26 de Julho, integravam, conforme mencionado, o Partido Unido da Revolução Socialista de Cuba. Não deixou, porém, de mencionar o fato de Marcos Rodríguez não ter feito nenhuma acusação "contra los compañeros procedentes del 26 de julio, ninguna acusación, ninguna insinuación, ninguna ofensa a los compañeros muertos, de la que era nuestra organización en aquel tiempo". (CASTRO, 1964, p. 68) Apesar da formação do sistema de partido único, os dirigentes revolucionários continuavam definindo sua identidade política em função de seu anterior pertencimento a uma das organizações revolucionárias, o que pode ser explicado, em parte, pelo antagonismo existente entre os grupos que conformavam o aparato político da Revolução e pela ausência, talvez inevitável nestas circunstâncias, de um projeto de governo que fosse suficientemente aglutinador.

Na condição de árbitro supremo do "caso Marquitos", Fidel Castro ocupou-se de julgar não apenas as organizações políticas, mas principalmente os dirigentes revolucionários. Como negava a natureza política da delação, ele isentou o PSP de quaisquer responsabilidades. Dentre os dirigentes que foram absolvidos pelo líder cubano, estava Edith Garcia Buchaca. Em sua confissão de culpa, Marcos Rodríguez declarou ter contado a esta dirigente toda a história que envolvia o episódio da delação, o que a tornava, consequentemente, cúmplice daquele crime. Esta versão conheceu, entretanto, intrigantes reviravoltas. Algum tempo depois da confissão de culpa, realizou-se uma acareação entre Edith García e Marcos Rodríguez, ocasião em que este, segundo Fidel Castro, além de negar o que havia declarado, ainda "inventa una cosa inusitada: que los agentes del Cuerpo de Seguridad lo sugirieron eso". (CASTRO, 1964, p. 75) Diante do tribunal, Marcos Rodríguez inicialmente silenciou a respeito do fato de Edith García conhecer a delação, mas, depois de encerrado o julgamento em primeira instância, o réu voltou a declarar que ela sabia do episódio da delação.

Em sua tentativa de explicar essas reviravoltas, Fidel Castro buscou formular uma espécie de teoria geral a partir de sua experiência em casos semelhantes, afirmando que a primeira declaração do autor de um crime não costuma conter "toda la verdad" e que réus confessos sempre buscam minorar "su responsabilidad". (CASTRO, 1964, p. 76) Aplicando essas máximas ao "caso Marquitos”, o líder cubano considerou que a confissão continha apenas

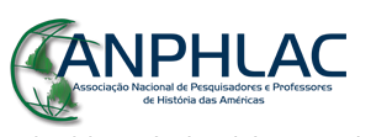

Revista Eletrônica da ANPHLAC, ISSN 1679-1061, №. 21, p. 04-33, Jul./Dez., 2016.

http://revista.anphlac.org.br 
uma parte da verdade, ou seja, a culpabilidade do réu. Avaliou, porém, como falsa a declaração que faria com que Edith García figurasse como cúmplice do crime e que havia sido expressa tanto na confissão de culpa quanto depois de encerrado o julgamento em primeira instância. A esse respeito, a versão aceita como verdadeira foi a da acareação, quando Marcos Rodríguez negou que Edith García soubesse que havia sido ele o delator. Fidel Castro demonstrou ainda que a sua capacidade de determinar o que era verdadeiro ou falso em cada declaração do processo judicial estava orientada por um princípio axiológico que se baseava na fidelidade revolucionária como um fator de mensuração da verdade, conforme expresso no trecho abaixo:

Y señores hay una cuestión de principios. Que es necesario que nosotros la establezcamos como una cuestión de principios. Y es el principio que jamás la palabra de un delator, de un individuo cuya conducta es un libro de vergüenza, de inescrupulosidad y de inmoralidad, de simulación, la palabra de un sujeto de esa índole, de un delator, jamás pueda enfrentarse a la palabra de un revolucionario cualquiera que sea su nivel. Cualquiera que sea su jerarquía desde la más alta hasta la más humilde. El día que aceptáramos ese principio, el día que renunciáramos a ese principio la honra de ningún revolucionario estaría segura. El prestigio de ningún revolucionario estaría seguro. La vida de ningún revolucionario, la honra, su historia estaría segura, porque estaría a merced de cualquier miserable delator que al borde del castigo merecido estaría dispuesto a lanzar lodo, a lanzar fango, e a lanzar división sobre los revolucionarios. (CASTRO, 1964, p. 76)

Orientado por esse princípio axiológico, o líder da Revolução expôs qual deveria ser o juízo correto a ser feito pelos demais revolucionários acerca da suposta cumplicidade de Edith García no crime de delação cometido por Marcos Rodríguez, expressando-se nos seguintes termos: "si somos hombres de principios, si somos hombres objetivos, debemos exonerar enteramente de esa imputación a la compañera Edith García Buchaca. Y que mantener dudas no sería exonerarla". (CASTRO, 1964, p. 76)

O único dirigente do PSP ao qual não se exonerou totalmente de culpa no "caso Marquitos" foi Joaquín Ordoqui, cujos vínculos estreitos com o réu tinham provocado em Fidel Castro verdadeira “indignación”. (CASTRO, 1964, p. 70) O líder cubano condenou publicamente Joaquín Ordoqui por ter permitido o ingresso de Marcos Rodríguez no PSP, por

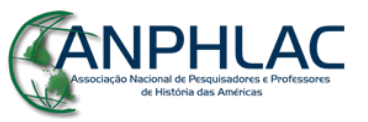

Revista Eletrônica da ANPHLAC, ISSN 1679-1061, №. 21, p. 04-33, Jul./Dez., 2016.

http://revista.anphlac.org.br 
ter dado "consejito a este señor" (CASTRO, 1964, p. 77) e por não ter comunicado imediatamente à direção do Partido (PURSC) o recebimento do que denominou de "carta chantaje" (CASTRO, 1964, p. 71) - em alusão à carta em que Marcos Rodríguez pedia ao dirigente do PSP que ele intercedesse a seu favor. Por essas razões, Fidel Castro reprovou Joaquín Ordoqui, vinculando à sua atitude "censurable" os demais acontecimentos do "caso Marquitos". Além disso, argumentou que "a un viejo militante revolucionario es correcto que se le exija el tratamiento adecuado a las cuestiones y no incurrir en errores de eso tipo". Recorrendo ao adágio popular segundo o qual "no hay mal que por bien no venga", Fidel Castro considerou que o esclarecimento do caso tanto do ponto de vista "legal" quanto "político" tinha sido útil, entre outros aspectos, para demonstrar que a disciplina era "el principio esencial de un revolucionario, de un marxista", bem como que a Revolução Cubana não seria "ni tolerante ni implacable". (CASTRO, 1964, p. 77) Neste sentido, o "caso Marquitos" foi utilizado para transmitir a ideia de que a Revolução era generosa não apenas com os inimigos, mas também com os próprios revolucionários. Para ilustrar essa generosidade com cada "compañero", o líder cubano recorreu à mitologia romana, ao afirmar o seu desejo de que fossem rechaçadas as ameaças da "Ley de Saturno":

¿Y cuál es la Ley de Saturno? Aquella ley clásica o dicho clásico o refrán clásico que dice que la revolución como Saturno devora a sus propios hijos. Que esta revolución no devore a sus propios hijos. Que la Ley de Saturno no imponga sus fueros, que las facciones no asomen por ninguna parte. (CASTRO, 1964, p. 77)

De acordo com Fidel Castro, qualquer ameaça dessa "ley maldita" seria enfrentada tanto por ele próprio quanto pelo povo, de modo que ninguém pudesse abusar do poder em Cuba e que os revolucionários se sentissem seguros. Nem tolerante nem implacável, a Revolução encarregava-se tão somente de aplicar a justiça para que nunca se pudesse dizer "que un solo revolucionario fue injustamente castigado... que un solo inocente fue fusilado. Que un solo hijo de la revolución fue devorado”. (CASTRO, 1964, p. 77)

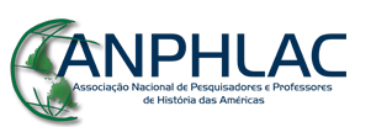

Revista Eletrônica da ANPHLAC, ISSN 1679-1061, №. 21, p. 04-33, Jul./Dez., 2016.

http://revista.anphlac.org.br 
Após tecer considerações acerca da unidade da Revolução e dos métodos justos e generosos com que esta tratava tanto os inimigos quanto os companheiros, Fidel Castro finalizou o seu depoimento como testemunha de acusação no tribunal revolucionário do mesmo modo como - na condição de comandante em chefe da Revolução e primeiro-ministro do governo - finalizava os seus discursos nas tribunas políticas instaladas nas cerimônias realizadas em praças públicas: gritando o lema “¡Patria o Muerte!” (CASTRO, 1964, p. 77) e sendo ovacionado com aplausos pelo público presente.

Em termos práticos, pode-se afirmar que o tribunal que julgou o "caso Marquitos" condenou dois "réus": Joaquín Ordoqui foi condenado politicamente, ao passo que Marcos Rodríguez foi condenado "juridicamente". Contudo, em relação a ambos os "réus" e em todas as etapas do processo judicial ficou evidente o caráter político do julgamento. Neste sentido, a atuação de José Antonio Grillo Longoria ${ }^{6}$, advogado de defesa de Marcos Rodríguez, é um dos exemplos mais emblemáticos do caráter político e, consequentemente, da insustentável aparência de legalidade jurídica do julgamento. José Grillo Longoria começou sua explanação afirmando que, na condição de advogado de ofício do Tribunal Supremo que julgava o caso, tinha sido encarregado da defesa de Marcos Rodríguez. Considerou, entretanto, que sua tarefa não era "agradable", já que se tratava do julgamento de um fato "tan repugnante" como "el delito de delación". (LONGORIA, 1964, p. 1) ${ }^{7}$

Consciente de que deveria atuar muito mais como revolucionário do que como jurista ainda mais depois de Fidel Castro ter criticado, diante do mesmo tribunal, membros da imprensa cubana que eram "más periodistas do que revolucionarios" (CASTRO, 1964, p. 73) -, o defensor do réu argumentou que, enquanto em uma sociedade burguesa o advogado recorre a todo tipo de artimanhas e mentiras para postular a inocência de seu representado, em uma sociedade socialista o advogado atua de modo distinto, uma vez que lhe interessa tão somente o "esclarecimiento de la verdad", razão pela qual os diferentes membros do tribunal - defesa,

\footnotetext{
${ }^{6}$ Em um dos documentos do processo judicial, o nome do advogado de defesa de Marcos Rodríguez é incorretamente grafado como José Antonio Grillo Noroña, substituindo-se, portanto, o seu sobrenome Longoria por Noroña.

${ }^{7}$ Tanto em seu título, "Vista del juicio que se sigue contra el procesado Marcos Armando Rodríguez Alfonso, celebrada el 30 de marzo de 1963" [sic], quanto no endereço de acesso, http://www.latinamericanstudies.org/cuba/3-30-1963.pdf, o documento em questão é erroneamente datado de 1963. No entanto, a data correta da realização desta sessão no Tribunal de Apelação foi 30 de março de 1964.
}

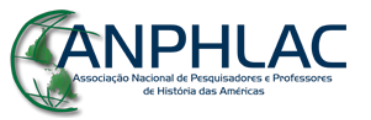

Revista Eletrônica da ANPHLAC, ISSN 1679-1061, №. 21, p. 04-33, Jul./Dez., 2016. 
promotoria, etc. - "no tienen ni deben tener posiciones antagónicas". (LONGORIA, 1964, p. 2) Seguindo uma linha argumentativa que se caracterizava mais pela defesa da Revolução do que de seu representado, José Grillo Longoria afirmou não ter dúvidas de que a confissão do réu não apenas havia sido espontânea, como também havia sido sincera. Além disso, assegurou que a defesa teve "todas las garantías y toda la libertad" para realizar seu trabalho. Todavia, preocupou-se em esclarecer que no exercício de sua função jamais pretendeu "proyectar sombra alguna sobre instituciones y hombres de la Revolución” (LONGORIA, 1964, p. 3), tendo ainda o cuidado para não produzir equívocos, pois, dessa forma, poderia oferecer "materia prima a los intrigantes, a la contrarrevolución para manufacturar sus asqueantes y miserables productos: la mentira, la infamia, la calumnia, el engaño”. (LONGORIA, 1964, p. 4)

Depois de feitas essas ressalvas, o advogado de defesa declarou que o seu objetivo era solicitar ao Tribunal de Apelação que o réu não fosse sancionado com a pena de morte. Apesar disso, reconheceu não haver argumentos sérios para defender a inocência de Marcos Rodríguez, uma vez que tinha ficado suficientemente comprovado que ele havia sido "el delator de Humboldt 7". De igual modo, admitiu não haver "pruebas serias ni argumentos serios" para declarar que o réu era "un demente y por lo tanto un absoluto inimputable". Preocupando-se em falar não apenas como jurista, mas principalmente como revolucionário, afirmou que não pediria clemência no julgamento do réu porque isso poderia significar que um delito daquela natureza não merecia a pena de morte, quando, ao contrário, entendia ser esta uma punição justa. Defendeu ainda ser "un derecho y un deber, de nuestra revolución socialista, aplicar la pena de muerte cuantas veces ello sea necesario". (LONGORIA, 1964, p. 5)

Exposta a sua posição política quanto à sentença que havia sido estabelecida para o réu em primeira instância, o advogado de defesa buscou fundamentar o seu pedido para converter a pena de morte em pena de prisão, argumentando que Marcos Rodríguez possuía uma "personalidad psicopática" (LONGORIA, 1964, p. 5) e que isto consistia em uma circunstância atenuante do crime. Valendo-se de adjetivos empregados pelas testemunhas de acusação para caracterizar o réu, o advogado de defesa dedicou-se fundamentalmente a compor o perfil psicológico de Marcos Rodríguez, apresentando-o como um indivíduo "psicopata, extraño, raro, vanidoso, exhibicionista”. (LONGORIA, 1964, p. 8) A essa lista, somaram-se vários outros epítetos com sentido também negativo, tais como: “engreído, vanidoso, simulador,

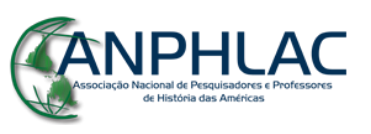

Revista Eletrônica da ANPHLAC, ISSN 1679-1061, №. 21, p. 04-33, Jul./Dez., 2016.

http://revista.anphlac.org.br 
conflictivo, intrigante, mentiroso, doble personalidad, etc.”. Quanto ao aspecto físico, ele foi apresentado como um indivíduo “débil” e "insignificante”. (LONGORIA, 1964, p. 17) Constam ainda referências que evidenciam a reprovação quanto às vestimentas de Marcos Rodríguez, por ele habitualmente usar "sandalias, saco amarillo". Em síntese, tratava-se de um indivíduo "muy raro", expressão empregada para aludir eufemicamente à sua homossexualidade. (LONGORIA, 1964, p. 13)

Em toda a explanação do defensor, a homossexualidade do réu é referida nas entrelinhas e utilizada como um dos fatores que, aliado ao perfil psicopata que lhe é atribuído, explicam a conduta traiçoeira na delação dos mártires de Humboldt 7. É particularmente interessante o modo como é explicada a motivação pessoal do delator. De acordo com o advogado de defesa, o réu utilizava a sua crescente capacidade intelectual como uma forma de compensar a sua “falta de valor" e o fato de ser um indivíduo débil “física y anímicamente”. (LONGORIA, 1964, p. 17) Por essa razão, Marcos Rodríguez havia se aproximado do grupo de intelectuais que integravam as entidades estudantis da Universidade, onde poderia satisfazer "su gran vanidad", lendo e escrevendo poemas com o intuito de ser o "centro de admiración" daquele grupo. (LONGORIA, 1964, p. 18) No entanto, o acirramento da luta contra o governo de Fulgencio Batista teria evidenciado o descompasso existente entre o réu e os integrantes do Diretório Revolucionário, os quais, mais tarde, seriam vitimados no crime de Humboldt 7. Esse descompasso seria explicado pelo fato de Marcos Rodríguez não se enquadrar no padrão de masculinidade que se esperava de todo revolucionário. Quando se impôs a necessidade da luta contra o governo de Fulgencio Batista, os integrantes do Diretório abandonaram temporariamente os afãs literários e partiram para a ação revolucionária. Desde então, "la admiración de todos" passou a ser "para los hombres, que exponen todos los días su vida contra los sicarios de la tiranía”. Dessa forma, ninguém pensava em Marcos Rodríguez, que estava perdendo "las oportunidades de satisfacer su vanidad", uma vez que já não mais havia interesse em sua “producción literaria”. (LONGORIA, 1964, p. 19)

As diferenças entre os mártires de Humboldt 7 e o seu delator estavam, portanto, claramente definidas. De um lado, estavam os integrantes do Diretório, que eram mais revolucionários do que intelectuais, sendo caracterizados como "hombres de acción", "hombres de coraje", "hombres de valor". (LONGORIA, 1964, p. 19) De outro lado, estava o indivíduo

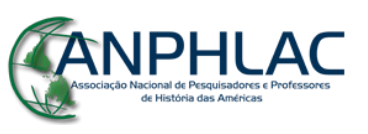

Revista Eletrônica da ANPHLAC, ISSN 1679-1061, №. 21, p. 04-33, Jul./Dez., 2016.

http://revista.anphlac.org.br 
"raro", que utilizava "su debilidad como una arma social" e tudo o que conseguia era inspirar "sentimientos maternales", "lastima” ou "desprecio". (LONGORIA, 1964, p. 17) Marcos Rodríguez possuía capacidade intelectual, mas não revolucionária, pois, ao aproximar-se dos homens de ação e de valor, apenas colocava em evidência "su cobardía". (LONGORIA, 1964, p. 19) Ainda de acordo com a interpretação de José Grillo Longoria, por não mais encontrar espaço para "brillar con su inteligencia" (LONGORIA, 1964, p. 21) e por ter sido criticado pelos integrantes do Diretório em virtude de sua "falta de valor" como revolucionário, Marcos Rodríguez teria nutrido ódio em relação àqueles "valiosos compañeros". (LONGORIA, 1964, p. 20) Esse ódio, os complexos que o réu possuía e a sua "personalidad anormal y psicopática" explicariam, portanto, "la decisión de producir la venganza". O crime de delação representou, segundo o defensor, a satisfação de um "impulso patológico" (LONGORIA, 1964, p. 21) e constituiu-se no meio pelo qual o réu, que não era um delator qualquer, mas um "verdadero genio del mal" (LONGORIA, 1964, p. 23), buscou "dar escape a su complejo". (LONGORIA, 1964, p. 22) Foi para este "gênio do mal" que o advogado de defesa pediu a reversão da pena de morte em pena de prisão, argumentando que o seu representado, apesar de não ser inimputável, não podia ser considerado plenamente responsável por seus atos. O Tribunal de Apelação, por sua vez, decidiu manter a pena de morte e, no dia 19 de abril de 1964, Marcos Rodríguez foi executado por um pelotão de fuzilamento.

\section{O "caso Ordoqui"}

O "caso Marquitos" não se encerrou, entretanto, com a condenação e o fuzilamento de Marcos Rodríguez, oficialmente, o único réu do caso. Conforme mencionado anteriormente, um dos resultados desse julgamento havia sido a condenação política de Joaquín Ordoqui. Pouco mais de seis meses depois de encerrado o "caso Marquitos", no qual havia figurado como "réu político", Joaquín Ordoqui foi submetido também à justiça revolucionária. Isto ocorreu porque, enquanto transcorria o julgamento de Marcos Rodríguez, surgiram denúncias de que, em 1958, durante o período em que esteve exilado no México, o então dirigente do PSP teria fornecido informações ao serviço de inteligência dos Estados Unidos. Em decorrência dessas

\section{CANPHLAC}

Revista Eletrônica da ANPHLAC, ISSN 1679-1061, №. 21, p. 04-33, Jul./Dez., 2016.

http://revista.anphlac.org.br 
denúncias, Joaquín Ordoqui foi condenado, em novembro de 1964, a 30 anos de prisão domiciliar por ter supostamente atuado como agente da CIA. Ele não chegou, porém, a cumprir integralmente a pena, por ter falecido em 1973. (ROJAS, 2009)

Militante do PSP desde longa data e fiel às diretrizes do Partido Comunista da União Soviética, Joaquín Ordoqui era um dos homens de confiança deste país em Cuba. Se, por um lado, isso lhe beneficiou, uma vez que o caráter especial e relativamente suave da pena - a detenção em seu próprio domicílio - teria sido decorrente das pressões exercidas pelo governo soviético (LA GRANGE, 2010), que, ao interceder a favor do réu, conseguiu evitar que ele recebesse uma punição mais severa como, por exemplo, ser encaminhado ao paredão de fuzilamento ou então encarcerado em um dos presídios cubanos, por outro lado, o fato de, naquele momento, ser talvez o principal homem de confiança da União Soviética parece ter sido justamente o que fez de Joaquín Ordoqui um obstáculo ao poder de Fidel Castro e determinou a sua defenestração.

Permeados por zonas de sombras, o "caso Marquitos" e o "caso Ordoqui" - etapas distintas de um só processo de defenestração política - ainda não oferecem elementos suficientes para uma interpretação conclusiva acerca de muitos de seus aspectos. No entanto, parece ser bastante plausível a hipótese de que o objetivo de anular politicamente Joaquín Ordoqui não se restringia a uma questão da política interna, estando ligado mais amplamente ao protagonismo com que Fidel Castro pretendia conduzir as negociações com a União Soviética em um período no qual as relações entre os dois países caracterizavam-se pela instabilidade decorrente de suas divergências político-ideológicas.

Alguns fatos fornecem indícios dessa provável vinculação entre o propósito de Fidel Castro de conduzir pessoalmente as negociações com a União Soviética e as suas investidas contra o homem de confiança do governo soviético na cúpula revolucionária cubana. $\mathrm{O}$ prestígio político de Joaquín Ordoqui com os dirigentes soviéticos teria ficado evidenciado em outubro de 1962, quando ele foi o principal interlocutor cubano durante as negociações secretas que tinham como objetivo solucionar a crise dos mísseis. (BARROSO, 2009) Depois disso, outros dois fatos parecem vincular importantes etapas de negociações entre Cuba e União Soviética com o tratamento político dado ao "caso Marquitos": a confissão de culpa de Marcos Rodríguez - que continha declarações que comprometiam Joaquín Ordoqui e Edith García

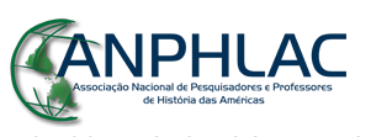


Buchaca - foi obtida, coincidentemente, alguns dias antes de Fidel Castro realizar a sua primeira visita oficial à União Soviética e aos países do Leste Europeu, em abril de 1963; e o início do julgamento do caso, em março de 1964, ocorreu pouco tempo depois do retorno do líder cubano de sua segunda visita a Moscou. Mesmo sendo apenas indícios, tais fatos contribuem para conferir plausibilidade à hipótese de que Fidel Castro pretendia se livrar de intermediários na condução das relações com a União Soviética.

Não há dúvidas, porém, de que o líder cubano tinha a intenção de anular politicamente Joaquín Ordoqui e de que utilizou o "caso Marquitos" para justificar, inclusive diante do governo soviético, essa defenestração ${ }^{8}$. A prova disso é o fato de que Joaquín Ordoqui foi o único dirigente revolucionário que não foi “absolvido" no "caso Marquitos". Se quisesse isentálo de culpa, Fidel Castro poderia ter recorrido a algum subterfúgio, como havia feito para inocentar Edith García Buchaca, em relação à qual defendeu o princípio de que a palavra de um revolucionário é mais fidedigna do que a de um indivíduo que pratica um ato contrarrevolucionário.

O critério distinto aplicado em relação a Edith García Buchaca - que estava tão a par das atividades de Marcos Rodríguez, tenham sido elas delituosas ou não, quanto Joaquín Ordoqui - suscita o questionamento acerca do porquê do empenho demonstrado por Fidel Castro em protegê-la de quaisquer acusações. O peso das relações pessoais no âmbito da cúpula revolucionária teria sido determinante nesse caso?

Ainda antes do triunfo da Revolução, Joaquín Ordoqui, Edith García Buchaca e Carlos Rafael Rodríguez envolveram-se em uma história de infidelidade conjugal. Enquanto era casada com Carlos Rafael Rodríguez, Edith García teve um relacionamento amoroso com Joaquín Ordoqui - à época, professor de Carlos Rafael na Universidade de Havana - e casouse com ele posteriormente. A história de traição, envolvendo os três integrantes do PSP, não ficou restrita às suas vidas particulares, pois os dirigentes do Partido decidiram discuti-la publicamente, tratando o episódio de traição conjugal como uma questão que "afectaba a la

\footnotetext{
${ }^{8}$ Joaquín Ordoqui era um dos homens de confiança da União Soviética em Cuba e possuía boas relações com o premiê Nikita Kruschev. Neste sentido, um dado curioso é que as denúncias de que Ordoqui havia atuado como agente da CIA começaram a surgir entre março e abril de 1964, durante o "caso Marquitos", mas Fidel Castro apenas determinou a prisão domiciliar do dirigente comunista em novembro do referido ano - coincidentemente ou não - um mês depois de Nikita Kruschev ter sido destituído do poder soviético. (BANDEIRA, 1998)
}

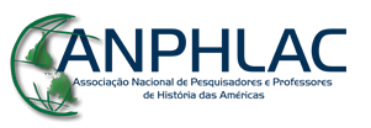

Revista Eletrônica da ANPHLAC, ISSN 1679-1061, №. 21, p. 04-33, Jul./Dez., 2016.

http://revista.anphlac.org.br 
moral colectiva de los miembros del Partido". (MONTANER, 2011) Após o triunfo da Revolução, Carlos Rafael, que havia demonstrado possuir ideias menos ortodoxas do que a maioria de seus correligionários do PSP, tornou-se amigo e um dos homens de confiança de Fidel Castro no governo revolucionário. Por ocasião do julgamento do "caso Marquitos", teria Carlos Rafael intercedido a favor de Edith García, com quem possuía duas filhas? Em caso positivo, teria sido essa intervenção determinante na decisão de Fidel Castro de isentá-la de quaisquer responsabilidades no "caso Marquitos"? Ou, desde o princípio, a intenção de Fidel Castro era investir tão somente contra Joaquín Ordoqui? Não se sabe se houve alguma interferência de Carlos Rafael Rodríguez no tratamento dado pelo governo revolucionário ao casal Ordoqui/García. É certo que Edith García também foi excluída da vida pública, mas diferentemente de seu marido, não esteve submetida a uma prisão domiciliar, podendo viajar a Madri para visitar umas das filhas que teve com Carlos Rafael. (MONTANER, 2011; RODRÍGUEZ, 2007)

Já em relação a Joaquín Ordoqui, como o líder cubano tinha a intenção de alijá-lo, foi conveniente adotar o princípio oposto ao que fora utilizado para defender Edith García, pois, desta vez, a palavra do inimigo foi considerada mais fidedigna do que a do revolucionário. De acordo com a versão do governo cubano, as denúncias que originaram o “caso Ordoqui” teriam sido reveladas por agentes da CIA a funcionários da embaixada cubana no México. Contudo, parece pouco provável que Joaquín Ordoqui tenha, de fato, fornecido informações ao serviço de inteligência dos Estados Unidos em 1958, durante o período em que esteve exilado no México. O que compromete a plausibilidade dessa acusação é menos o fato de que se tratava de um comunista de longa data, leal ao PCUS, do que a estranha coincidência de que a acusação acerca de uma suposta colaboração com a CIA tenha vindo à tona justamente durante o julgamento do "caso Marquitos", quando Fidel Castro condenava politicamente Joaquín Ordoqui.

A acusação de que esse dirigente colaborou com a CIA teria sido inventada pelo governo cubano - depois de terem ficado evidentes os distintos critérios com que os dirigentes revolucionários foram julgados no "caso Marquitos" - como uma estratégia para retirá-lo de uma vez da vida pública e fundamentar de forma mais consistente o seu expurgo? Ou essa acusação contra o homem de confiança do governo soviético teria sido fabricada pela CIA com

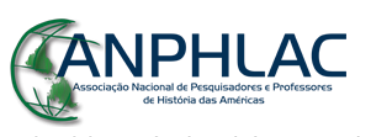

Revista Eletrônica da ANPHLAC, ISSN 1679-1061, №. 21, p. 04-33, Jul./Dez., 2016.

http://revista.anphlac.org.br 
o objetivo não apenas de fomentar a divisão no seio da cúpula revolucionária cubana, mas principalmente de fazer com que a União Soviética se indispusesse com o líder cubano em um momento no qual os dois países empreendiam uma reaproximação política? Caso as denúncias tenham sido realmente forjadas pela CIA, resta saber: Fidel Castro teria acreditado na palavra do inimigo - sem suspeitar de suas possíveis intenções - ou tirado proveito dela para livrar-se de um dirigente que era visto como um obstáculo a seu protagonismo na condução da Revolução?

Seja qual for a resposta correta para cada uma dessas perguntas, não há dúvidas de que a defenestração de Joaquín Ordoqui interessava a Fidel Castro. Diferentemente do que havia acontecido com Aníbal Escalante, não incidia sobre Joaquín Ordoqui nenhuma acusação de que ele tencionava usurpar o poder e assumir o comando da Revolução. No entanto, houve alguns aspectos em comum no expurgo desses dois dirigentes revolucionários, que eram oriundos das fileiras do PSP. Em ambos os casos, Fidel Castro condenou o que qualificou como condutas contrarrevolucionárias dos dois dirigentes, evitando fazer críticas diretas ao PSP, tanto porque dependia de seus quadros políticos capacitados no aparato administrativo da Revolução quanto pelo fato de que não lhe convinha incompatibilizar-se com todos os comunistas de longa data do país e, por extensão, com o governo soviético, já que o PSP - que havia sido extinto por ocasião da formação das ORI - seguia as diretrizes do Partido Comunista da União Soviética. No expurgo desses dois dirigentes revolucionários ficou evidenciado também que ser o homem de confiança da União Soviética equivalia, em contrapartida, a ser visto com suspeição pelo líder máximo da Revolução Cubana, passando a figurar como uma ameaça ou um obstáculo a seu poder. O fato de, em maio de 1960, o governo cubano ter nomeado Faure Chomón dirigente oriundo do Diretório Revolucionário e marcadamente anticomunista durante o

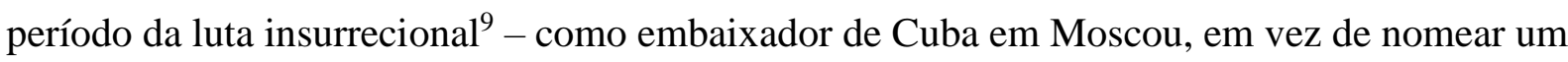

\footnotetext{
${ }^{9}$ A partir da declaração de Fidel Castro, em 1961, de que o marxismo-leninismo passava a ser a ideologia oficial da Revolução Cubana, houve, logicamente, uma conversão generalizada ao socialismo por parte de dirigentes revolucionários oriundos do Movimento 26 de Julho e do Diretório Revolucionário 13 de Março. Neste sentido, alguns trechos do testemunho de Faure Chomón durante o julgamento do "caso Marquitos" são emblemáticos das metamorfoses por que passou o regime cubano. São exemplos disso tanto a negação que o dirigente faz de seu anterior anticomunismo quanto a sua preocupação em afirmar retroativamente o anti-imperialismo do Diretório Revolucionário, aludindo inclusive ao fato de a Revista Alma Mater - publicação da Universidade de Havana que foi o principal veículo de divulgação das ideias da Federação de Estudantes Universitários (FEU) - conter citações de frases de Lênin como uma evidência do anti-imperialismo dos integrantes do Diretório Revolucionário,
}

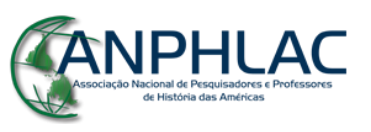

Revista Eletrônica da ANPHLAC, ISSN 1679-1061, №. 21, p. 04-33, Jul./Dez., 2016.

http://revista.anphlac.org.br 
integrante do PSP, parece ser um indício de que os vínculos entre a União Soviética e os seus homens de confiança em Cuba eram vistos com certo temor por Fidel Castro.

A força política dos dirigentes do PSP na cúpula revolucionária decorria principalmente do fato de terem sido eles os principais promotores do estreitamento de vínculos entre Cuba e União Soviética e de, a partir de então, virem desempenhando o papel de intermediários nas negociações entre os governos dos dois países. Convém lembrar que no decorrer dos anos 1960 as relações cubano-soviéticas estavam assentadas em bases bastante instáveis, uma vez que Cuba, mesmo dependente nos campos econômico e militar, reivindicava independência político-ideológica em relação à União Soviética. Quanto a este último aspecto, o governo soviético parece ter compreendido a estratégia política a que atendia a profissão de fé marxistaleninista feita por Fidel Castro e, não bastasse isso, ainda reprovava a heterodoxia dos recémconvertidos comunistas cubanos. O intuito de Fidel Castro de anular politicamente alguns dirigentes do PSP parece estar associado principalmente ao temor de que, em face de uma situação de disputa na política interna cubana, a União Soviética pudesse preteri-lo, apoiando os comunistas de longa data oriundos das fileiras do PSP, alguns dos quais se constituíam nos homens de confiança do governo soviético em Cuba.

A defenestração política de alguns dirigentes revolucionários não se explica, no entanto, pelo simples fato de eles serem procedentes das fileiras do PSP, pois tanto Aníbal Escalante e Joaquín Ordoqui, que foram presos e apontados como contrarrevolucionários, quanto Carlos Rafael Rodríguez, que se tornou um dos homens de confiança de Fidel Castro e chegou a ser vice-presidente dos conselhos de Estado e de Ministros de Cuba, pertenceram a este partido. Portanto, o líder cubano não investiu indistintamente contra todos os dirigentes revolucionários provenientes do PSP, mas sim contra aqueles que, fiéis às diretrizes do Partido Comunista soviético, demonstraram menor conformidade em relação à heterodoxia e às sucessivas metamorfoses político-ideológicas do castrismo.

Antes mesmo que findasse a década de 1960, Fidel Castro já havia defenestrado os dirigentes revolucionários que discordaram de sua forma de conduzir a Revolução e, por

organização política que havia sido qualificada como "pequeno-burguesa" por Marcos Rodríguez. (CHOMÓN, 1964)

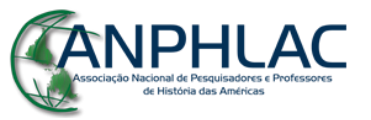

Revista Eletrônica da ANPHLAC, ISSN 1679-1061, №. 21, p. 04-33, Jul./Dez., 2016.

http://revista.anphlac.org.br 
conseguinte, anulado o poder de contestação dos demais. O líder máximo da Revolução investiu tanto contra dirigentes anticomunistas, que se opunham à radicalização das reformas e reivindicavam o retorno à legalidade democrática, quanto contra comunistas de longa data que criticavam aspectos como, por exemplo, a heterodoxia ideológica do governo cubano. Fidel Castro apropriou-se de determinados postulados ideológicos do marxismo-leninismo, estreitou as relações com a União Soviética e, em seguida, anulou politicamente os velhos comunistas e o seu trabalho de intermediários políticos, tornando-se ele próprio o principal interlocutor do governo soviético. (BARROSO, 2009) Conforme argumenta Elizabeth Burgos, o alijamento de comunistas de longa data constitui uma evidencia de que "lo que hizo del castrismo una dictadura, no fue su ideología socialista o marxista, sino la visión totalitaria de Fidel Castro que instrumentalizó el comunismo para su proyecto totalitario". (BURGOS, 2009) Por meio de uma política de defenestração de dirigentes revolucionários de diferentes matizes ideológicos, Fidel Castro logrou exercer controle absoluto sobre as distintas organizações políticas que se uniram para compor o sistema de partido único, uma das bases de sustentação do regime cubano.

\section{Considerações finais}

A análise das sessões dos tribunais revolucionários cubanos não deixa dúvidas quanto à insustentável aparência de legalidade jurídica que se pretendeu dar a julgamentos que tinham, de fato, um caráter político ${ }^{10}$. A indução dos réus às autocríticas; a preocupação dos advogados de defesa em demonstrar que eram mais revolucionários do que juristas; e a uniformidade

\footnotetext{
${ }^{10}$ Ressalvadas as diferenças institucionais e de contexto histórico, esta afirmativa acerca da aparente legalidade jurídica que se buscou conferir a um julgamento de cunho político aplica-se perfeitamente ao processo de impeachment da presidente Dilma Rousseff que está atualmente em curso no Brasil e que se configura como um golpe de Estado. Nas sessões realizadas na Câmara dos Deputados e no Senado Federal acerca do processo de impeachment, evidenciou-se o caráter político do julgamento. A maioria dos parlamentares ignorou a discussão jurídica sobre a existência/ausência de crime de responsabilidade. Muitos deles declararam seus votos favoráveis ao impeachment antes mesmo que fossem realizadas as sessões destinadas aos debates acerca do referido processo no Congresso Nacional. Em seus discursos, citaram a baixa popularidade da presidente e a crise econômica que o Brasil atravessa como justificativas para o impeachment, permitindo perceber a natureza política do julgamento. A articulação das forças conservadoras da classe política e da sociedade civil brasileira em torno do impeachment da presidente Dilma Rousseff evidencia a fragilidade da democracia no Brasil e a persistência de características de uma cultura política autoritária.
}

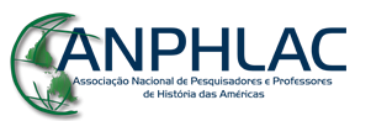

Revista Eletrônica da ANPHLAC, ISSN 1679-1061, №. 21, p. 04-33, Jul./Dez., 2016.

http://revista.anphlac.org.br 
discursiva de todos os envolvidos no julgamento - que pareciam repetir frases e jargões empregados por Fidel Castro - são apenas alguns exemplos da farsa jurídica de tribunais onde o que estava em jogo eram as condutas políticas de dirigentes revolucionários e sua lealdade ao líder da Revolução.

Mais do que apenas evidenciar aspectos da história política de Cuba sob a Revolução, o exame das sessões desses tribunais revolucionários diz muito acerca de uma cultura política autoritária que foi predominante sob a ordem mundial da Guerra Fria e que se manifestou de maneira particularmente acentuada na América Latina. $\mathrm{O}$ uso de um vasto vocabulário bélico e a interpretação da realidade a partir de termos binários, orientados por uma lógica da confrontação, são características que evidenciam a concepção militarista que guiava a política dos diversos regimes autoritários em tempos de Guerra Fria. Em tais regimes, as posições políticas daqueles que lhes eram favoráveis ou contrários não eram pensadas a partir da relação aliados/adversários, sendo concebidas, com base em uma perspectiva antagônica mais extrema, a partir da contraposição amigos/inimigos ${ }^{11}$.

Essa concepção da política como um campo de lutas que opõe amigos a inimigos refletiu-se nos modos como diferentes regimes autoritários trataram os antagonismos decorrentes da adesão ou oposição a um determinado projeto político. A tendência de considerar opositores políticos como inimigos e de dispensar-lhes tratamento condizente com esta concepção esteve presente, por exemplo, nas diversas ditaduras latino-americanas, sob a vigência das quais inúmeros opositores políticos foram alvos de políticas de Estado que

\footnotetext{
${ }^{11}$ Manifestando-se tanto nos discursos quanto em outras práticas políticas dos regimes autoritários, a tendência de considerar opositores políticos como inimigos encontra estreitas correspondências no âmbito da teoria política. No entendimento do teórico alemão Carl Schmitt, a essência da política é o seu caráter antagonístico, o qual se expressa por meio dos enfrentamentos que opõem amigos a inimigos. Segundo esse autor, dentre os diversos tipos possíveis de enfrentamento, destaca-se o confronto bélico, estando a guerra no horizonte de possibilidades reais e, além disso, constituindo-se no momento por excelência em que a tensão conflitiva na qual está baseada a contraposição amigo/inimigo torna-se mais evidente. (SCHMITT, 1998) A concepção da política como um campo de guerra situa-se no centro das estratégias utilizadas pelo estado autoritário/totalitário para justificar a repressão. Afinal, se as questões da política são concebidas como uma guerra, urge que lhes seja dado um tratamento de guerra. Isso, porém, não significa que apenas em regimes autoritários/totalitários e com base na relação amigo/inimigo seja possível conceber o caráter conflitivo da política. Neste sentido, Claude Lefort considera que a política é essencialmente um campo de conflitos também em regimes democráticos. A diferença é que, nestes, mais do que a simples distinção na terminologia dos antagonistas - aliados/adversários em vez de amigos/inimigos -, a existência de conflitos não implica em um tratamento de guerra. (LEFORT, 2011)
}

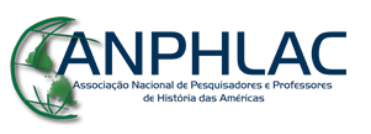

Revista Eletrônica da ANPHLAC, ISSN 1679-1061, №. 21, p. 04-33, Jul./Dez., 2016.

http://revista.anphlac.org.br 
determinavam - consoante o grau de ameaça que esses indivíduos representavam - censurálos, prendê-los, torturá-los, exilá-los, assassiná-los.

O fato de as práticas políticas autoritárias do regime cubano não terem sido uma excepcionalidade, encontrando equivalências naquelas que foram adotadas por outros regimes autoritários no contexto da Guerra Fria - seja em âmbito latino-americano, seja em âmbito mundial -, não deve, porém, servir de pretexto para justificá-las. A análise das implicações da Guerra Fria favorece uma compreensão mais holística do autoritarismo político que predominou no período, mas não o justifica. Os regimes ditatoriais, sejam eles de direita ou de esquerda, devem ser criticados histórica e historiograficamente. Em contrapartida, é urgente a defesa das práticas políticas e dos valores democráticos, ainda mais em regiões como a América Latina, onde as democracias, a despeito da retórica sobre sua consolidação, ainda padecem de incrível fragilidade. 


\section{Fontes e referências bibliográficas}

ANGUREL, Julio Soto. La chivatería [2010]. Disponível em: <http://julio-sotoangurel.blogspot.com.br/2010/10/la-chivateria-por-julio-soto-angurel.html>. Acesso em: 13 dez. 2015.

BANDEIRA, Luiz Alberto Moniz. De Martí a Fidel: a Revolução Cubana e a América Latina. Rio de Janeiro: Civilização Brasileira, 1998.

BARROSO, Miguel. Castro ha monopolizado la historia de Cuba [entrevista concedida a Luis Marchal]. El siglo, n. 852, 19 oct. 2009. Disponível em: <http://www.elsiglodeuropa.es/siglo/historico/2009/852/852culturaBarroso.html >. Acesso em: 13 dez. 2015.

BURGOS, Elizabeth. El castrismo y medio siglo de amnesia [2009]. Disponível em: $<$ http://www.analitica.com/opinion/opinion-nacional/el-castrismo-y-medio-siglo-deamnesia/>. Acesso em: 13 fev. 2016.

CASTRO, Fidel. Comparecencia del Primero Ministro del Gobierno Revolucionario, Comandante Fidel Castro, en el juicio de apelación en la causa seguida contra Marcos Rodríguez Alfonso, delator de los mártires de Humboldt 7, Tribunal Supremo, Palacio de Justicia, La Habana, 26 de marzo de 1964. Revista Bohemia, Año 56, p. 60-77, 3 abr. 1964. Disponível em: <http://www.latinamericanstudies.org/cuba/Bohemia-4-3-1964.pdf>. Acesso em: 8 dez. 2015.

CHOMÓN, Faure. Declaración del testigo Comandante Faure Chomón Mediavilla en el juicio seguido al delator de los mártires de Humboldt 7 en la sala cuarta de la Audiencia de La Habana [1964]. Disponível em: <http://www.latinamericanstudies.org/cuba/Faure-Chomontestimonio.pdf >. Acesso em: 8 dez. 2015.

DEL RISCO, Enrico. El caso Marquitos (final) [2009]. Disponível em: $<$ http://enrisco.blogspot.com.br/2009/07/el-caso-marquitos-final.html>. Acesso em: 15 jan. 2016.

LA GRANGE, Bertrand de. La Revolución devora a sus hijos [2010]. Disponível em: <http://www.razon.com.mx/spip.php?article19504>. Acesso em: 15 jan. 2016.

LEFORT, Claude. A invenção democrática: os limites da dominação totalitária. 3. ed. Belo Horizonte: Autêntica, 2011.

LONGORIA, José Antonio. Grillo. Vista del juicio que se sigue contra el procesado Marcos Armando Rodríguez Alfonso, celebrada el 30 de marzo de 1963 [sic]; [1964]. Disponível em: <http://www.latinamericanstudies.org/cuba/3-30-1963.pdf>. Acesso em: 8 dez. 2015.

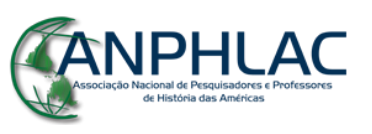

Revista Eletrônica da ANPHLAC, ISSN 1679-1061, №. 21, p. 04-33, Jul./Dez., 2016.

http://revista.anphlac.org.br 
MONTANER, Carlos Alberto. Historia genital de la Revolución Cubana [2011]. Disponível em: <http://www.diariodecuba.com/cuba/1308303016_1799.html>. Acesso em: 11 dez. 2015.

PRADO, Giliard S. Guerrilhas da memória: estratégias de legitimação da Revolução Cubana. 2013. 258 f. Tese (Doutorado em História) - Programa de Pós-Graduação em História, Universidade de Brasília, Brasília, 2013.

RODRÍGUEZ, Osvaldo Fructuoso. Humboldt 7 y el hombre que delató a mi padre. Miami Herald, 20 abr. 2007. Disponível em: <http://www.autentico.org/oa09876.php>. Acesso em: 23 jan. 2016.

ROJAS, Rafael. ¿Un misterio revelado? [2009]. Disponível em: <http://www.librosdelcrepusculo.net/2009/09/un-misterio-revelado.html>. Acesso em: $11 \mathrm{dez}$. 2015 .

SCHMITT, Carl. El concepto de lo político. Madrid: Alianza, 1998. 